\title{
How does financial literacy impact on inclusive finance?
}

\author{
Morshadul Hasan * (), Thi Le and Ariful Hoque
}

*Correspondence:

arif.morshad@gmail.com

Murdoch Business School,

Murdoch University,

Perth 6150, Australia

\begin{abstract}
Inclusive finance is a core concept of finance that makes various financial products and services accessible and affordable to all individuals and businesses, especially those excluded from the formal financial system. One of the leading forces affecting people's ability to access financial services in rural areas is financial literacy. This study investigated the impacts of financial knowledge on financial access through banking, microfinance, and fintech access using the Bangladesh rural population data. We employed three econometrics models: logistic regression, probit regression, and complementary log-log regression to examine whether financial literacy significantly affects removing the barriers that prevent people from participating and using financial services to improve their lives. The empirical findings showed that knowledge regarding various financial services factors had significant impacts on getting financial access. Some variables such as profession, income level, knowledge regarding depositing and withdrawing money, and knowledge regarding interest rate highly affected the overall access to finance. The study's results provide valuable recommendations for the policymaker to improve financial inclusion in the developing country context. A comprehensive and long-term education program should be delivered broadly to the rural population to make a big stride in financial inclusion, a key driver of poverty reduction and prosperity boosting.
\end{abstract}

Keywords: Financial knowledge, Financial literacy, Bank, Microfinance, FinTech, Financial inclusion, Inclusive finance, Bangladesh, Knowledge economy

JEL Classification: G2, G4, G5, D1, D9, O2, R1

\section{Introduction}

With the support of inclusive finance, the rural population has contributed significantly to the entire economy's development (Hasan et al. 2020b; Johnston 2005; Le et al. 2019; Stein 2010). Therefore, promoting financial services access to inclusive people will deeply connect them with the significant growth of the whole financial systems (Hasan et al. 2020b, 2020c; Rashidin et al. 2020b). Access to financial services is the most critical factor working behind the financial exclusion of the rural population. Chao et al. (2021) mentioned that financial inclusion is deeply connected to poverty reduction. However, both formal and informal financial institutions are responsible for providing financial access to those financially excluded people (Helms author(s) and the source, provide a link to the Creative Commons licence, and indicate if changes were made. The images or other third party material in this article are included in the article's Creative Commons licence, unless indicated otherwise in a credit line to the material. If material is not included in the article's Creative Commons licence and your intended use is not permitted by statutory regulation or exceeds the permitted use, you will need to obtain permission directly from the copyright holder. To view a copy of this licence, visit http:// creativecommons.org/licenses/by/4.0/. 
2006; Hussain et al. 2018; Zulkhibri 2016). The crucial obstacle of financial inclusion process is financial illiteracy (Bongomin et al. 2016a; Grohmann et al. 2018; Hasan et al. 2020a; Kodongo 2018; Koomson et al. 2019; Lyons and Kass-Hanna 2019; Mogilevskii and Asadov 2018; Segre 2018).

Nowadays, consumers have to specify a comprehensive range of financial products and services. Financial literacy, particularly the saliency and relevance of financial education regarding financial products, services, and activities (Fernandes et al. 2014; Sun et al. 2020), has played a crucial role in helping people select suitable financial products (Bianchi 2018; van Rooij et al. 2011; Von Gaudecker 2015). Financial literacy has a strong link with the development of every country's financial systems. It has dramatical implications on financially personal decisions making (Kezar and Yang 2010; Lusardi and Mitchell 2014; Maturana and Nickerson 2019; Paiella 2016; Rashidin et al. 2020a) and economic development by increasing economic security and decreasing unemployment (Berry et al. 2018; Hogarth 2006; Pompei and Selezneva 2019). Financial education improves people's understanding of different financial products and concepts through various instructions, information, and advice to develop financial risks and opportunities recognition skills. As a person with a low-level knowledge of financial activities is more likely to make financial errors, investors should enhance their financial knowledge to improve their portfolio performance. Financial education involves planning, investing, and saving, relying on formal financial methods such as financial calculators, methods, financial education-related seminars to help people make a sound financial decision (Lusardi 2012; Lusardi and Mitchell 2011).

Bangladesh is an emerging market economy with an overpopulation of around 166 million people. The country's high population density is leading to different financial and economic problems. One of the prevalent burning issues in such countries consists of access to financial products and services. Almost $53 \%$ of adult people are excluded from financial access, especially low-income groups (LightCastle Partners 2019). Although the number of banks is increasing day by day, no noticeable improvement has been reported. A large proportion of the rural population is still out of formal financial services. Millions of people in the countryside do not know about banking services, FinTech, and microfinance. Thus, research on financial literacy and financial access has been highly demanded in Bangladesh. However, limited studies are investigating the impact of financial knowledge on finance access for rural areas. These issues motivate us to conduct an empirical analysis to show the impact of financial literacy on the rural population's finance services access.

This study aims to investigate the impact of financial literacy on financial access through three sections: (i) impact on banking access, (ii) impact on microfinance access, and (iii) impact on mobile banking access. We employ logit and probit models to examine financial literacy's impact on getting financial access. Also, a robustness test is conducted using complementary log-log regression to prove the significance of our expected models.

The empirical findings show that financial knowledge has a significant effect on getting financial access. Some variables such as profession, income level, education level, knowledge regarding depositing and withdrawing money, and knowledge regarding interest rate are highly significant for overall financial access. However, training on different 
services is insignificant because of the low response rate in all cases. In most circumstances, rural residents are not aware of financial service training.

This study is a reflection of the timely demand of financial literacy because knowledge regarding financial services is receiving significant attention from researchers, government officials and educators, and policymakers (Berry et al. 2018; Frisancho 2019; Lusardi et al. 2019; Opletalová 2015; Postmus et al. 2013; Urban et al. 2018). It will significantly contribute to the current literature in inclusive finance, rural development, financial literacy, economic development, banking, and microfinance.

The paper is divided into six sections. The first to third sections include an introduction, review of the literature, and theoretical discussion, respectively. The methodology is explained in section four. The results and findings are reported in Sect. 5. Finally, Sect. 6 discusses the results, theoretical and practical implications, and future research directions.

\section{Literature review}

\section{Financial literacy and banking access}

Kou et al. (2021) identified access to finance as a challenge; thereby, financial literacy is treated as one of the influential financial inclusion components by different national and international organisations. Lyons and Kass-Hanna (2019) found that economically vulnerable populations are considerably less likely to be included in the financial systems. Also, higher levels of financially literate people are more likely to be engaged in positive savings behaviours and less likely to borrow from different informal sources. Financial literacy helps educate and empower people to evaluate various financial products and services. Bongomin et al. (2016b) raised questions about financial literacy's impact on financial inclusion, emphasising social capital. The findings showed that financial literacy indirectly affected financial inclusion through complete mediation of social capital. The absence of social capital might lead to financial literacy failure in boosting the level of financial inclusion among Uganda poor rural households. Hussain et al. (2018) examined the relationship between education level and business owners' engagement with financial services. They identified that financial literacy positively influenced a firm's access to finance and a firm's growth. Shen et al. (2019) showed a statistically meaningful association between digital financial product usage and financial literacy, except internet usage.

\section{Financial literacy and microfinance}

Nawaz (2015) focused on financial literacy with women empowerment. A right socioeconomic empowerment level is possible for women who can utilise their money effectively and efficiently with enough financial literacy competence. They usually gain training programs offered by the different microfinance agencies. Many NGOs are offering various training programs to their account holders. This financial literacy training helps women better understand the productive use of money, such as remaining bank accounts, utilising money effectively and efficiently, advising their husband and other family members about different economic activities. The women can take control of the overall financial situation of their families. The author finally concluded that the financial training component should be a must for all microfinance programs. Bijli (2012) highlighted that the financial literacy regarding microfinance included four thematic areas; 
budgeting, saving, debt management, and bank services. These four thematic areas are considered into two aspects; current behaviour and desired behaviour. The current behaviour related to budgeting for day-to-day living, reactive financial behaviour, lack of forwarding financial planning, wasteful expenditures, irregular savings, savings not linked to goals, borrow for emergencies, over-indebtedness, borrowing with little understanding of terms, limited knowledge of bank services, limited use of bank services. The desired behaviours involved planning for expenditures, making a budget, using a budget to manage money, avoiding unnecessary spending, having a savings plan, saving regularly, maintaining an emergency savings account, making a plan to reduce debt, avoiding excessive debt, borrowing with a full understanding of terms, knowing about financial options, their terms and conditions, and using bank services to support financial goals.

\section{Financial literacy and FinTech usage}

Financial technology is playing a very significant role in providing financial access to rural people. Mobile banking is an alternative replacement when people fail to reach banking services. They are very willing to deals in financial communication as it is comparatively easy to access and available everywhere in the country (Hasan et al. 2020b). Brown and Slagter van Tryon (2010) mentioned financial education as one of the most popular financial and economic terms of this Twenty-first century because of the growing use of technologies. In this case, it required tech education to look for new ways to operate new financial technologies. Every type of financial communication is based on technology, causing tech education and financial education in the current century's financial communication. Shen et al. (2019) specified that financial literacy worked as a significant force in bridging the gap between frequent internet usage and low financial management usage. Financial literacy reflected consumers' educational level, and the usage of financial literacy in FinTech influenced digital financial inclusion. Also, financial literacy increased the likelihood of using digital financial products and services to improve financial access (Hasan et al. 2020c). Only financial literacy alone did not influence financial inclusion, but the combination of financial literacy and internet usage could improve better financial access. Belayeth Hussain et al. (2019) recognised the reliability of financial education and financial literacy for financial stability. Lyons and Kass-Hanna (2019) found that respondents from the high-income economies' areas were significantly more likely to engage in online payments. They were also expected to make financial transactions using their mobile phones more frequently than in lowincome economies where most people are uneducated.

\section{Theoretical discussion}

\section{Financial literacy for rural people}

Financial literacy arises with the debate of financial exclusion, financial market fluctuation, deprivation of financial access, and inability to financial communication. Different literature expressed the meaning of financial literacy with specified areas where they find interest. This study highlights every definition in the perspectives of financial access. Recently, financial literacy has become a prominent issue on the financial and economic agenda worldwide (Williams and Satchell 2011; Postmus et al. 2013). Financial literacy is treated as having the proper knowledge of making the right decision in 
choosing financial products and services (Fernandes et al. 2014). Understanding financial language is crucial to improve financial education. Worthington (2016) highlighted financial literacy as the ability to decision-making in all aspects of people's budgeting, saving, and spending matters. Huston (2010) specified financial knowledge as an input to model the need for financial education and explain variation in financial outcomes. Wang et al. (2020) identified that poor knowledge regarding financial issues increases the chances of making unsecured P2P loans and personal loans.

In this study, the rural population's financial literacy represents their knowledge about financial services and activities in formal and informal economic sectors. The financial knowledge level of the rural group is completely different from the educated group. The basic financial knowledge is whether they know various financial services or not and how much they know about the general financial terms relating to banking, microfinance, and mobile banking.

\section{Access through banking}

The first aspect of financial access is banking services, which are the formal way of providing financial communication and services. Being able to access a bank account is the first step toward greater financial inclusion because a transaction account helps people reach broader financial services (Bhaskar 2013; Helms 2006; Patwardhan et al. 2018). It is suggested that all adults have access to appropriate financial products and services, mainly by banks (Demirguc-Kunt et al. 2017). Financial access through banking allows the countryside households to save money, support their business and family plans, hedge against everyday risks, and promote their economic activities (Sinha et al. 2018; Sun 2017; Wall 2017).

\section{Access through microfinance}

The second most effective way of financial access is microfinance, which is regarded as a valuable and powerful tool for poverty reduction. It is also specified as the provision of financial services for poor households. Cull and Morduch (2018) proposed a broader notion, "financial inclusion", for microfinance activities, such as providing savings, insurance, and payment services in under-served communities. Microfinance is also a solution to bring credit markets to underprivileged people on self-employment. It provides self-employment opportunities for the rural population (Cull et al. 2009; Morduch 1999). In remote areas where banks cannot deliver their services, microfinance replaces banks to provide the countryside residents with financial assistance.

\section{Access through FinTech}

FinTech is trendy in the present financial market, and its rapid development is an emerging issue of the financial world (Casanova et al. 2018; Gai et al. 2018; Gimpel et al. 2017; Hasan et al. 2020b, 2020c). FinTech refers to a combined form of 'Finance' \& 'Technology' (Zavolokina et al. 2016). The terms' Internet finance,' 'FinTech', and 'digital finance', 'mobile banking' are almost similar in meaning and used interchangeably worldwide (Hasan et al. 2020b, 2020c). Beyond the traditional financial systems, the involvement of digital financial services in the inclusive financial sector is reflected by the emerging issue' FinTech.' It relates to a wide range of financial services such as online banking, 


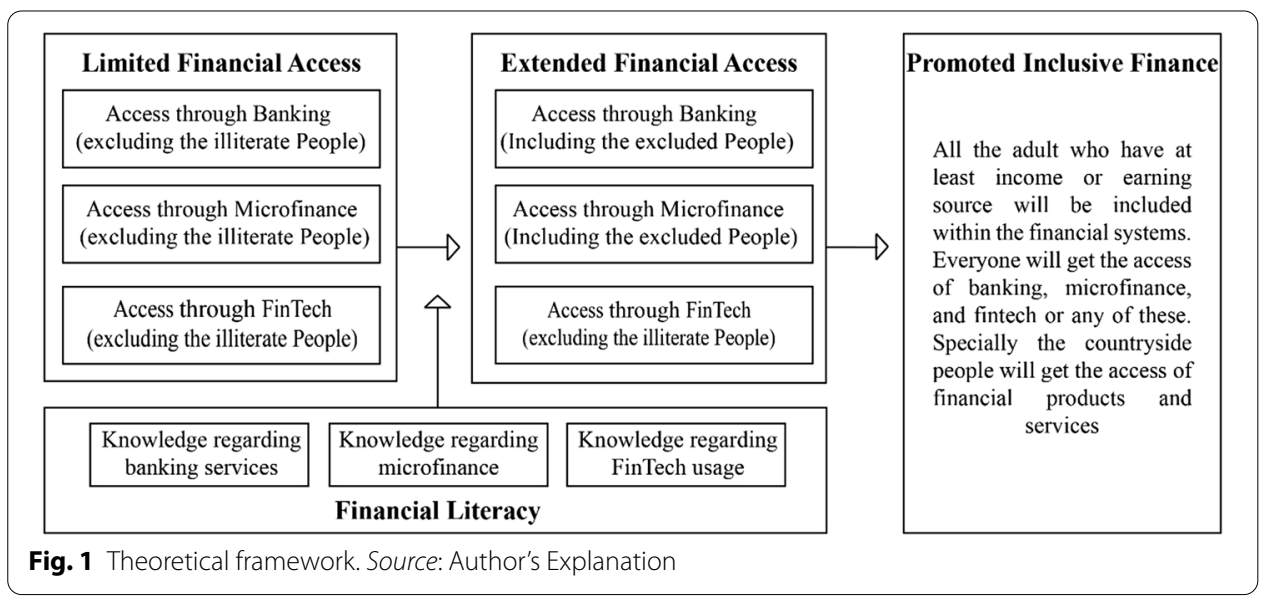

third-party payment, direct sales of funds, online insurance, crowdfunding, and online banking (Claessens et al. 2002; Hill and Hill 2018; Salampasis and Mention 2018).

\section{Conceptual framework}

Financial access is categorised into three parts; financial access through banking, financial access through microfinance, and financial access through financial technology (mobile banking). This research's theoretical structure is given in Fig. 1.

According to Fig. 1, there are three stages of promoting rural finance or inclusive finance: limited financial access, extended financial access, and advanced inclusive finance. The concept of promoted inclusive finance has been taken from (Hasan et al. 2020b). In the limited financial access stages, illiterate people are completely excluded from financial institutions' products and services. The second stage is financial access extension, where financial literacy works as moderating factor. Financial literacy helps to provide necessary financial knowledge to the rural illiterate people. After achieving proper financial knowledge relating to financial activities and services, those people are also included in the financial access group. Finally, the theory of more financial involvement of rural people contributes more to the rural economy, and the country's entire economy positively affects rural finance promotion. All the adults who have at least an income or earning source will be included within the financial systems.

\section{Methodology}

\section{Research procedure and sample characteristics}

Our sample consisted of 852 participants from three main populous cities in Bangladesh, including the capital (Dhaka) and the other two industrially developed cities (Gazipur and Narayongonj). We selected the respondents if they were 18 years of age or over and should have at least earning sources. Millions of people are working in these cities from all around the country. Therefore, getting a respondent who has at least earning source is comparatively more possible than in other areas or cities. Participants' age, level of education, professional status, as well as income were obtained. A random sampling process was applied in the entire data collection process. The study followed an analysis of literature review and reports to develop a set 
Table 1 Sample distribution. Source: Survey Questionnaire

\begin{tabular}{llll}
\hline Variables & Categories & Frequency & $\%$ \\
\hline Age & Below 25 & 228 & 26.7 \\
& 26 to 30 years & 252 & 29.5 \\
& 31 to 35 years & 180 & 21.1 \\
& 36-40 years & 102 & 11.9 \\
& 40 years plus & 90 & 10.5 \\
Education & No Education & 6 & 0.70 \\
& Primary Level & 228 & 26.7 \\
& Secondary Education & 354 & 41.4 \\
& Higher Secondary & 162 & 18.9 \\
Profession & Graduation & 102 & 11.9 \\
Income & Business/Self employment & 345 & 40.5 \\
& Job & 507 & 59.5 \\
& Below 10,000 (below USD 120) & 186 & 21.8 \\
& $10,001-20,000$ (USD120 to USD 235) & 456 & 53.5 \\
& 20,001-30,000 (USD 235 to USD 350) & 126 & 14.8 \\
& 30,001-50,000 (USD 350 to USD 600) & 60 & 7 \\
& 50,000 Plus (USD 600 plus) & 24 & 2.8 \\
\hline
\end{tabular}

of questionnaires. The questionnaire will be sent to targeted respondents randomly after a direct presence in some local residency areas. An invitation 852 completed questionnaires were received and analysed. Table 1 provides general information collected from the participants. We divided respondents into 5 age groups: $26.7 \%$ were below 25, 29.5\% were between 26 and 30 years old, $21.1 \%$ were between 31 and 35 years old, $11.9 \%$ were between 36 and 40 years old, and $10.5 \%$ were 40 or over. More than $87 \%$ of respondents had a higher secondary education level or lower. $40 \%$ of the participants had their own business while the remaining were employees. The majority of respondents had an income between BDT10001 and 20,000 (USD 120$\$ 235$ ), our study's prominent target. The detailed sample distribution is shown in Table 1.

The measurement of the questionnaire was segmented into four sections. The first section dealt with social-demographic information: name, age, educational level, income range, and location. The last three sections involved participants' usage of banking, micro-finance, and FinTech. Participants were asked about their access to banking services, microfinance, and FinTech. The answers were coded to be "1" if the respondents have utilised the services and " 0 " if they did not use them. We measured and defined the variables based on different perspectives. The respondent's knowledge level toward banking services and microfinance was assessed on a five-point Likert scale ranging from 1 (poor) to 5 (excellent). The measuring and determining of all the variables are taken from Kadoya et al. (2018). Mainly the concept of the variables used in this study was selected from the research of Adele Atkinson (2017), Atkinson (2015), Atkinson and Messy (2012), Bongini et al. (2018), OECD (2011), Williams and Satchell (2011). Table 2 presents the measurement of the variables. 
Table 2 Measurement of variables. Source: Authors' experiment

\begin{tabular}{|c|c|}
\hline Variables & Definition and Measurement \\
\hline \multicolumn{2}{|l|}{ Common variables } \\
\hline Profession & $\begin{array}{l}\text { The profession of the respondents }(1=J o b, 0=\text { Busi- } \\
\text { ness) }\end{array}$ \\
\hline Education & $\begin{array}{l}\text { The educational level of the respondents (Higher edu- } \\
\text { cation }=5 \text {, Below } \mathrm{HSC}=4, \text { Below } \mathrm{SSC}=3, \text { Primary }=2 \text {, } \\
\text { No }=1 \text { ) }\end{array}$ \\
\hline Income & $\begin{array}{l}\text { The income range of the respondents }(50,000 \text { Plus }=5 \\
\begin{array}{l}30,000-50,000=4,20,000-30,000=3,10,000- \\
20,000=2, \text { Below } 10,000=1)\end{array}\end{array}$ \\
\hline \multicolumn{2}{|l|}{ Banking variables } \\
\hline Bank account & $\begin{array}{l}\text { Whether the respondent has a bank account or not } \\
\text { (dummy) }\end{array}$ \\
\hline Deposit \& withdraw ability & $\begin{array}{l}\text { Respondents' ability to deposit into a bank account } \\
\text { (dummy) }\end{array}$ \\
\hline Bank training & $\begin{array}{l}\text { Whether the respondents have training on banking } \\
\text { services (dummy) }\end{array}$ \\
\hline Kn DPS \& loan & $\begin{array}{l}\text { The knowledge level of respondents on bank deposits } \\
\text { or savings (Excellent }=5 \text {, Very Good =4, Good =3, } \\
\text { Fair }=2 \text {, Poor }=1 \text { ) }\end{array}$ \\
\hline Kn DPS \& Loan Int. rate & $\begin{array}{l}\text { The knowledge level of respondents on saving interest } \\
\text { rate (Excellent }=5 \text {, Very Good }=4 \text {, Good }=3 \text {, Fair }=2 \text {, } \\
\text { Poor }=1 \text { ) }\end{array}$ \\
\hline Kn of security money & $\begin{array}{l}\text { The knowledge level of respondents on bank security } \\
\text { money (Excellent }=5 \text {, Very Good }=4, \text { Good }=3 \text {, } \\
\text { Fair }=2, \text { Poor }=1 \text { ) }\end{array}$ \\
\hline Bank Kn instalments & $\begin{array}{l}\text { The knowledge level of respondents on bank instal- } \\
\text { ments (Excellent }=5 \text {, Very Good }=4, \text { Good }=3 \text {, } \\
\text { Fair }=2, \text { Poor }=1 \text { ) }\end{array}$ \\
\hline \multicolumn{2}{|l|}{ Microfinance variables } \\
\hline Microfinance account & $\begin{array}{l}\text { Whether the respondent has a Microfinance or NBFIs } \\
\text { account (dummy) }\end{array}$ \\
\hline Deposit \& withdraw ability & $\begin{array}{l}\text { Respondents'ability to deposit money to their account } \\
\text { (dummy) }\end{array}$ \\
\hline MF training & $\begin{array}{l}\text { Whether the respondents have training on different } \\
\text { services relating to microfinance or NBFIs (dummy) }\end{array}$ \\
\hline Kn savings \& loan & $\begin{array}{l}\text { The knowledge level of respondents on deposits or } \\
\text { savings to micro-finance (Excellent }=5 \text {, Very Good }=4 \\
\text { Good }=3 \text {, Fair }=2 \text {, Poor }=1 \text { ) }\end{array}$ \\
\hline Kn savings \& loan Int, rate & $\begin{array}{l}\text { The knowledge level of respondents on the micro- } \\
\text { finance saving interest rate (Excellent }=5 \text {, Very } \\
\text { Good }=4 \text {, Good }=3 \text {, Fair }=2 \text {, Poor }=1 \text { ) }\end{array}$ \\
\hline Kn security money & $\begin{array}{l}\text { The knowledge level of respondents on micro-finance } \\
\text { security money (Excellent }=5 \text {, Very Good }=4 \text {, } \\
\text { Good = 3, Fair }=2, \text { Poor }=1 \text { ) }\end{array}$ \\
\hline Kn installment & $\begin{array}{l}\text { The knowledge level of respondents on micro-finance } \\
\text { instalments (Excellent }=5 \text {, Very Good = 4, Good =3, } \\
\text { Fair }=2, \text { Poor }=1 \text { ) }\end{array}$ \\
\hline \multicolumn{2}{|l|}{ FinTech variables } \\
\hline FinTech account & $\begin{array}{l}\text { Whether the respondent has a mobile banking account } \\
\text { (dummy) }\end{array}$ \\
\hline Send \& withdraw money & $\begin{array}{l}\text { Whether the user can send money to others account } \\
\text { (dummy) }\end{array}$ \\
\hline FT training & $\begin{array}{l}\text { Whether the users have training on mobile banking } \\
\text { (dummy) }\end{array}$ \\
\hline FT bill pay & $\begin{array}{l}\text { The ability to pay different bills of government services } \\
\text { such as electricity bills, gas bills, and other govern- } \\
\text { ment services bill (dummy) }\end{array}$ \\
\hline
\end{tabular}


Table 2 (continued)

\begin{tabular}{ll}
\hline Variables & Definition and Measurement \\
\hline FT software use & $\begin{array}{l}\text { Whether the respondents can operate the software or } \\
\text { they use the key-press options (dummy) } \\
\text { FT online deal }\end{array}$ \\
$\begin{array}{l}\text { Whether the respondents can deal in online shopping } \\
\text { with their mobile banking account (dummy) }\end{array}$ \\
\hline
\end{tabular}

Table 3 Reliability statistics. Source: Author explanation

\begin{tabular}{lllll}
\hline Model & Cronbach's Alpha & Variables & Observation & Interpretation \\
\hline Banking model & 0.907 & 8 & 852 & Excellent \\
Microfinance model & 0.868 & 9 & 852 & Good \\
FinTech model & 0.795 & 8 & 852 & Adequate \\
Overall & 0.912 & 19 & 852 & Excellent \\
\hline
\end{tabular}

\section{Analytical procedure}

The analysis was conducted in three steps: (a) based on participants' self-reported behaviour, respondents were identified as banking, microfinance, and FinTech user or non-user, respectively; (b) the confirmatory factor analysis (CFA) was used to determine whether the covariates are significantly related to their factors or not; (c) binary regression was conducted to test the real impact of financial literacy on the three elements (banking, microfinance, and FinTech access). Hassan Al-Tamimi and Anood Bin Kalli (2009), Fernandes et al. (2014), Kiliyanni and Sivaraman (2018), Agyei (2018), and Ouma et al. (2017), and Feng et al. (2019) used a probabilities regression model to estimate the impact of financial literacy in different circumstances. There are two commonly used models for binary dependent variables; these are the logit and probit models. This study followed probability distributions. The following algorithm follows the econometrics modelling of this study;

$$
\log (p)=\log \left(\frac{p}{(1-p)}\right)=\beta_{0}+\beta_{1} X_{1}+\beta_{2} X_{2}+\cdots+\beta_{n} X_{n}
$$

The term $\log \left(\frac{p}{1-p}\right)$ is called the logit function, and it has a natural interpretation as the logarithm of odds. The logistic model is widely used for binomial data and is implemented in many statistical programs.

\section{Reliability test}

The reliability test value ranges between 0 and 1.00, with 0 indicates no reliability and 1.00 means perfect reliability. The larger value of the reliability coefficient, the more reliable the test scores. Table 3 present the reliability statistics of this study. According to the reliability test, all models had acceptable Cronbach's alpha values. After the separate reliability test for each model (banking model, microfinance model, FinTech model), the overall reliability test with all the variables was conducted. The Cronbach's alpha value of the overall reliability test was 0.912 , representing excellent reliability. 
Table 4 Descriptive statistics. Source: Author's findings

\begin{tabular}{|c|c|c|c|c|c|}
\hline List of variables & $\mathrm{N}$ & Min & Max & Mean & Std. Deviation \\
\hline Profession & 852 & 0 & 1 & 0.60 & 0.492 \\
\hline Income & 852 & 1 & 5 & 2.15 & 0.938 \\
\hline Education & 852 & 1 & 5 & 3.15 & 0.973 \\
\hline \multicolumn{6}{|l|}{ Phase 1-banking variables } \\
\hline Bank account & 852 & 0 & 1 & 0.61 & 0.490 \\
\hline Deposit \& withdraw ability & 852 & 0 & 1 & 0.63 & 0.483 \\
\hline DPS \& loan & 852 & 1 & 5 & 2.37 & 1.228 \\
\hline DPS \& loan interest rate & 852 & 1 & 5 & 2.26 & 1.157 \\
\hline Installment & 852 & 1 & 5 & 2.78 & 1.308 \\
\hline Security money & 852 & 1 & 5 & 2.24 & 1.224 \\
\hline Bank training & 852 & 0 & 1 & 0.14 & 0.348 \\
\hline \multicolumn{6}{|l|}{ Phase 1-Microfinance variables } \\
\hline Microfinance account & 852 & 0 & 1 & 0.45 & 0.498 \\
\hline Deposit \& withdraw ability & 852 & 0 & 1 & 0.47 & 0.500 \\
\hline DPS \& loan & 852 & 1 & 5 & 2.36 & 1.191 \\
\hline DPS \& Ioan Interest rate & 852 & 1 & 5 & 2.02 & 1.131 \\
\hline Installment & 852 & 1 & 5 & 2.49 & 1.290 \\
\hline Security money & 852 & 1 & 5 & 2.17 & 1.189 \\
\hline Personal investment & 852 & 1 & 5 & 2.25 & 1.294 \\
\hline Microfinance training & 852 & 0 & 1 & 0.06 & 0.244 \\
\hline \multicolumn{6}{|l|}{ Phase 1_FinTech variables } \\
\hline FinTech account & 852 & 0 & 1 & 0.70 & 0.460 \\
\hline Money send \& withdraw ability & 852 & 0 & 1 & 0.62 & 0.486 \\
\hline Billpay ability & 852 & 0 & 1 & 0.32 & 0.466 \\
\hline Software use ability & 852 & 0 & 1 & 0.44 & 0.498 \\
\hline Online dealings ability & 852 & 0 & 1 & 0.29 & 0.454 \\
\hline FinTech training & 852 & 0 & 1 & 0.18 & 0.382 \\
\hline
\end{tabular}

\section{Findings and analysis}

The Logit model, Probit model, and complementary log-log regression model were employed to show the likelihood of getting financial access in the rural area. Also, confirmatory factor analysis and descriptive statistics were presented as empirical findings.

\section{Descriptive statistics}

First of all, Table 4 presents the descriptive statistics of the three models' variables. This table has four phases: common variables, banking variables, microfinance variables, and financial technology variables.

According to Table 3, most of the respondents were service holders (60\%), the average income structure of the respondents was 2.15 , which referred to 10,001 to 20,000 BDT (USD120 to USD 240). The education level is 3.15, which means most of the respondents obtained the secondary education level (almost $42 \%$ of all the respondents). On average, $60 \%$ of the respondents had banking access, and most of the respondents know how 
to deposit money into the bank and withdraw money from their accounts. Though the mean score of the knowledge regarding deposit and withdrawal ability from a bank was above the average, the knowledge regarding DPS and loan, knowledge regarding DPS \& loan interest rate, and knowledge regarding security money had a below-average mean value $(2.37,2.26$, and 2.24 respective). It indicated that the respondents have moderate knowledge regarding those three variables. However, the respondent had good knowledge about bank instalments for a loan or fixed deposit, with the mean value of knowledge regarding instalment was 2.78 .

On the other hand, only $45 \%$ of respondents had microfinance access. As stated earlier, if someone has access to a banking account, she/he knows how to deposit and withdraw from the personal microfinance account. The mean value of the deposit and withdrawal ability was 0.47 , almost similar to the microfinance account $(0.45)$. The mean value of knowledge regarding DPS and loan was virtually more than fair (2.36); however, knowledge regarding DPS \& loan interest rate was approximately fair (2.02). The respondents had good knowledge regarding instalment (2.49). The mean value of knowledge regarding security money and personal investment was good (2.17 and 2.25, respectively). The mean value of 0.06 for microfinance training, indicating respondents almost had training on microfinance activities.

Nowadays, almost 75 per cent of the populations have mobile banking access. ${ }^{1}$ This study has found that nearly $70 \%$ of people had FinTech access, one of the most promising financial inclusion factors in financial technology (Hasan et al. 2020b, 2020c). It is a noticeable fact that regardless of whether the respondent has a bank account/microfinance account, respondents prefer a mobile banking account. That is why almost $62 \%$ of people could send money and withdraw money from their accounts. However, there is one critical issue that some people have FinTech access to, but they don't know how to send money to others account and withdraw from their account. In these cases, they depend entirely on others. Who are mobile banking agents for sending and withdrawing cash? Except mobile banking software using ability (mean value 0.46 ), other variables such as bill pay through mobile banking, online dealings ability, and FinTech training had comparatively lower mean values, suggesting that respondents are not familiar with these activities. Finally, the more educated people had a high possibility to have FinTech access.

\section{Confirmatory Factor Analysis}

The confirmatory factor analysis (CFA) was employed to achieve a clear view of the data and use the output in subsequent analyses by running logit and probit regressions. The majority of variables show statistically significant standardised factor loading value with a $p$-value of more than 0.001 . The exception occurred for the income variable of microfinance accounts holders, which experienced an insignificant $p$-value, 0.173 . The result suggested that the independent variables were significantly related to their factors (see Table 5). Also, Appendix 1 presents the variance and covariance of the variables.

\footnotetext{
${ }^{1}$ https://thefinancialexpress.com.bd/views/money-transfer-through-mobile-phones-1580483374
} 
Table 5 Standardised factor loading and significance tests. Source: Authors' experiment

\begin{tabular}{|c|c|c|c|c|c|c|}
\hline \multirow[t]{2}{*}{ Variables } & \multicolumn{2}{|l|}{ Banking } & \multicolumn{2}{|c|}{ Microfinance } & \multicolumn{2}{|l|}{ Fintech } \\
\hline & Coef & z & Coef & z & Coef & $z$ \\
\hline \multirow[t]{2}{*}{ Profession } & $0.1269^{* * *}$ & 3.77 & $0.5331^{* * *}$ & 40.78 & $0.5503^{* * *}$ & 41.87 \\
\hline & $(0.0337)$ & & $(0.0131)$ & & $(0.0131)$ & \\
\hline \multirow[t]{2}{*}{ Income } & $0.5181^{* * *}$ & 20.67 & 0.0466 & 1.36 & $0.2726^{* * *}$ & 8.60 \\
\hline & $(0.0251)$ & & $(0.0342)$ & & $(0.0317)$ & \\
\hline \multirow[t]{2}{*}{ Education } & $0.4642^{* * *}$ & 17.27 & $-0.138^{* * *}$ & -4.10 & $0.3845^{* * *}$ & 13.17 \\
\hline & $(0.0269)$ & & $(0.0336)$ & & $(0.0292)$ & \\
\hline \multirow[t]{2}{*}{ Deposit \& withdraw ability } & $0.9121^{* * *}$ & 158.32 & $0.9017^{* * *}$ & 140.75 & & \\
\hline & $(0.0058)$ & & $(0.0064)$ & & & \\
\hline \multirow[t]{2}{*}{ DPS \& loan } & $0.7288^{* * *}$ & 45.36 & $0.8572^{* * *}$ & 130.21 & & \\
\hline & $(0.0161)$ & & $(0.0135)$ & & & \\
\hline \multirow[t]{2}{*}{ DPS \& loan interest rate } & $0.6937^{* * *}$ & 39.03 & $0.6225^{* * *}$ & 29.67 & & \\
\hline & $(0.0178)$ & & $(0.0210)$ & & & \\
\hline \multirow[t]{2}{*}{ Instalment } & $0.6595^{* * *}$ & 34.06 & $0.7633^{* * *}$ & 53.38 & & \\
\hline & $(0.0194)$ & & $(0.0143)$ & & & \\
\hline \multirow[t]{2}{*}{ Security money } & $0.6065^{* * *}$ & 28.00 & $0.7298^{* * *}$ & 45.57 & & \\
\hline & $(0.0217)$ & & $(0.0160)$ & & & \\
\hline \multirow[t]{2}{*}{ Personal investment } & & & $0.6331^{* * *}$ & 30.84 & & \\
\hline & & & $(0.0205)$ & & & \\
\hline \multirow[t]{2}{*}{ Send \& withdraw ability } & & & & & $0.8097^{* * *}$ & 68.65 \\
\hline & & & & & $(0.0118)$ & \\
\hline \multirow[t]{2}{*}{ Billpay ability } & & & & & $0.4159 * * *$ & 14.68 \\
\hline & & & & & $(0.0283)$ & \\
\hline \multirow[t]{2}{*}{ Software use Ability } & & & & & $0.5268^{* * *}$ & 21.29 \\
\hline & & & & & $(0.0248)$ & \\
\hline \multirow[t]{2}{*}{ Online dealing ability } & & & & & $0.3861^{* * *}$ & 13.24 \\
\hline & & & & & $(0.0292)$ & \\
\hline \multirow[t]{2}{*}{ FinTech training } & & & & & $0.2644^{* * *}$ & 8.30 \\
\hline & & & & & $(0.0319)$ & \\
\hline
\end{tabular}

The Comparative fit index (CFI) value for each single model is 1.0 , the value of Prob >chi2 is $0.000 .{ }^{* * *}$ refers the $p$-value is more than 0.001 , the value within the first bracket is the OIM standard error

According to Appendix 1, the covariance of banking access and FinTech access was significant; however, the other two covariance shows insignificant $p$-values.

\section{Regression results}

Table 6, 7, 8, and 9 present the regression results of two separate models (logit and probit regression model). Each model has been shown into two categories, A and B, where part A excluded the model's common variables and part B included all variables. The banking access model is presented as in Eq. (2):

$$
\begin{aligned}
& \text { Logit }(\text { BankAccount })=\beta_{0}+\beta_{1} * \text { Profession }+\beta_{2} * \text { Income }+\beta_{3} * \text { Education } \\
& \quad+\beta_{4} * \text { Deposit \& Withdraw Ability }+\beta_{5} * \text { Kn of DPS \& Loan } \\
& \quad+\beta_{6} * \text { Kn of DPS \& Loan Interest Rate }+\beta_{7} * \text { Kn of Installment } \\
& +\beta_{8} * \text { Kn of Security Money }+\varepsilon_{i}
\end{aligned}
$$


Table 6 Regression result of banking access and financial literacy. Source: Author's Study

\begin{tabular}{|c|c|c|c|c|}
\hline \multirow[t]{2}{*}{ Bank account (DV) } & \multicolumn{2}{|l|}{ Logit } & \multicolumn{2}{|l|}{ Probit } \\
\hline & A & B & A & B \\
\hline \multirow[t]{2}{*}{ Profession } & & $2.641^{* * *}$ & & $1.253^{* * *}$ \\
\hline & & $(0.611)$ & & $(0.290)$ \\
\hline \multirow[t]{2}{*}{ Income } & & $2.774^{* * *}$ & & $1.411^{* * *}$ \\
\hline & & $(0.689)$ & & $(0.342)$ \\
\hline \multirow[t]{2}{*}{ Education } & & $1.505^{* * *}$ & & $0.814^{* * *}$ \\
\hline & & $(0.440)$ & & $(0.231)$ \\
\hline \multirow[t]{2}{*}{ Deposit \& withdraw ability } & 6.085 & $7.495^{* * *}$ & 3.117 & $3.915^{* * *}$ \\
\hline & $(0.659)$ & $(1.016)$ & $(0.288)$ & $(0.484)$ \\
\hline \multirow[t]{2}{*}{ DPS \& loan } & 1.176 & 0.803 & 0.585 & 0.448 \\
\hline & $(0.441)$ & $(0.527)$ & $(0.236)$ & $(0.278)$ \\
\hline \multirow[t]{2}{*}{ DPS \& loan interest rate } & 3.295 & $3.765^{* * *}$ & 1.517 & $2.059^{* * *}$ \\
\hline & $(0.574)$ & $(0.666)$ & $(0.249)$ & $(0.356)$ \\
\hline \multirow[t]{2}{*}{ Installment } & 0.337 & 0.326 & 0.100 & 0.180 \\
\hline & $(0.253)$ & $(0.304)$ & $(0.135)$ & $(0.169)$ \\
\hline \multirow[t]{2}{*}{ Security money } & -1.603 & -0.493 & -.607 & -0.336 \\
\hline & $(0.523)$ & $(0.592)$ & $(0.249)$ & $(0.301)$ \\
\hline \multirow[t]{2}{*}{ _cons } & -9.72 & -15.09 & -4.83 & -7.67 \\
\hline & $(1.066)$ & (2.184) & $(0.491)$ & $(1.037)$ \\
\hline
\end{tabular}

This model presents the association between financial literacy and banking access. Part A of the logit model shows -82.60 log-likelihood, $L R$ chi $^{2}(5)$ is 977.61 , and model fits at $85.54 \%$ Pseudo $R^{2}$ value; where part B shows -61.84 log-likelihood, $L R$ $\mathrm{chi}^{2}$ (8) is 1019.12, and model fits at $89.18 \%$ Pseudo $\mathrm{R}^{2}$ value. On the other hand, Part A of the Probit model shows -83.57 log-likelihood, $L R$ chi $^{2}(5)$ is 975.66 , and the model fits at $85 \%$ Pseudo $R^{2}$ value; where part B shows -62.88 log-likelihood, LR $\mathrm{chi}^{2}(8)$ is 1017.04 , and model fits at $89 \%$ Pseudo $\mathrm{R}^{2}$ value. The value of $\mathrm{Prob}>\mathrm{Chi}^{2}$ is 0 for all models, and the observation of A \& B is $852 . * * * * *{ }^{*}$ refer significance level at $99 \%, 95 \%, 90 \%$, respectively. The value within the first bracket is the standard error value

The dependent variable was coded 1 if the respondent had a personal bank account and coded 0 if the respondent was not the bank account holder. The independent variables, including profession, and money deposit and withdrawal ability, are dummy variables. The other independent variables, such as income, education, knowledge (Kn) of savings \& loans, knowledge of savings \& loan interest rate, knowledge of instalment, knowledge of security money, are categorical with a five-point Likert scale.

Table 6 presents the regression results of the banking access model. All common variables (profession, income, education) were found to significantly impact an individual's banking access. People with higher income and higher education are more likely to open a bank account. For the banking-related variables, the knowledge regarding deposit and withdrawal ability significantly affected the finance access $(p=0.000)$ with the highest coefficient (7.495), suggesting that rural residents considered the ability to deposit and withdraw as their primary driven factor of opening an account. Similarly, savings and loan interest rates substantially influenced people's use of banking products and services (coefficient $=3.765$ and $p=0.000$ ).

The microfinance access model is presented in Eq. (3) as given below: 
Table 7 Regression result of microfinance access and financial literacy. Source: Author's Findings

\begin{tabular}{|c|c|c|c|c|}
\hline \multirow[t]{2}{*}{ Microfinance (DV) } & \multicolumn{2}{|c|}{ Logit model } & \multicolumn{2}{|c|}{ Probit model } \\
\hline & A & B & $A$ & B \\
\hline \multirow[t]{2}{*}{ Profession } & & -1.534 & & $-1.051^{*}$ \\
\hline & & $(1.037)$ & & $(0.562)$ \\
\hline \multirow[t]{2}{*}{ Income } & & $-5.221^{* * *}$ & & $-2.937^{* * *}$ \\
\hline & & $(1.535)$ & & $(0.818)$ \\
\hline \multirow[t]{2}{*}{ Education } & & $1.756^{* * *}$ & & $0.845^{* *}$ \\
\hline & & $(0.666)$ & & $(0.358)$ \\
\hline \multirow[t]{2}{*}{ Deposit \& withdraw ability } & 10.007 & $22.55^{* * *}$ & 5.178 & $11.874^{* * *}$ \\
\hline & $(1.459)$ & $(5.487)$ & $(0.694)$ & $(2.822)$ \\
\hline \multirow[t]{2}{*}{ Savings \& loan } & 2.523 & $5.911^{* * *}$ & 1.113 & $3.040^{* * *}$ \\
\hline & $(0.504)$ & $(1.615)$ & $(0.225)$ & $(0.817)$ \\
\hline \multirow[t]{2}{*}{ Savings \& loan interest rate } & 1.159 & $4.580^{* * *}$ & 0.808 & $2.537^{* * *}$ \\
\hline & (0.439) & $(1.475)$ & $(0.234)$ & $(0.775)$ \\
\hline \multirow[t]{2}{*}{ Installment } & -0.226 & 0.989 & -0.004 & 0.576 \\
\hline & (0.338) & $(0.835)$ & $(0.174)$ & $(0.418)$ \\
\hline \multirow[t]{2}{*}{ Security money } & 2.654 & $4.708^{* * *}$ & 1.252 & $2.541^{* * *}$ \\
\hline & $(0.502)$ & $(1.160)$ & $(0.245)$ & $(0.608)$ \\
\hline \multirow[t]{2}{*}{ Personal investment } & -1.311 & $-4.143^{* * *}$ & -0.662 & $-2.138^{* * *}$ \\
\hline & $(0.408)$ & $(1.093)$ & $(0.209)$ & $(0.570)$ \\
\hline \multirow[t]{2}{*}{ _cons } & -17.418 & -39.24 & -9.196 & -20.45 \\
\hline & (2.551) & (10.744) & $(1.289)$ & $(5.471)$ \\
\hline
\end{tabular}

This model presents the association between financial literacy and microfinance access. Part A of the logit model shows - 63.24 log-likelihood, LR chi ${ }^{2}(6)$ is 1046.35, and model fits at $89 \%$ Pseudo $R^{2}$ value; where part B shows -43.701 log-likelihood, $L R$ chi $^{2}(9)$ is 1085.41 , and model fits at $93 \%$ Pseudo $R^{2}$ value. On the other hand, Part $A$ of the Probit model shows -65.67 log-likelihood, $L R$ chi $^{2}(6)$ is 1041.48 , and the model fits at $88 \%$ Pseudo $R^{2}$ value; where part $B$ shows -44.97 log-likelihood, $\mathrm{LR} \mathrm{chi}^{2}(9)$ is 1082.89, and model fits at $92 \%$ Pseudo $\mathrm{R}^{2}$ value. The value of Prob $>\mathrm{chi}^{2}$ is 0 for all models, and the observation of $A \& B$ is $852 . * * *, * * * *$ refer significance level at $99 \%, 95 \%, 90 \%$, respectively. The value within the first bracket is the standard error value

$$
\begin{aligned}
& \text { Logit }(\text { MFAcc })=\beta_{0}+\beta_{1} * \text { Profession }+\beta_{2} * \text { Income }+\beta_{3} * \text { Education } \\
& \quad+\beta_{4} * \text { Deposit \& Withdraw Ability }+\beta_{5} * \text { Kn of DPS \& loan } \\
& \quad+\beta_{6} * \text { Kn DPS \& Loan Interest Rate }+\beta_{7} * \text { Kn of Installment } \\
& +\beta_{8} * \text { Kn of Security Money }+\beta_{9} * \text { Kn of Personal Investment }+\varepsilon_{i}
\end{aligned}
$$

The dependent variable was coded 1 if the respondent had a microfinance or NBFI account. However, it was coded 0 if the respondent was not the microfinance and NBFI holder. The independent variables such as profession and deposit \& withdrawal ability are dummy variables. Other independent variables, knowledge of savings and loans, knowledge of savings and loan interest rate, knowledge of instalments, knowledge of security money, knowledge of personal investment, are categorical with a five-point Likert scale.

Table 7 presents the regression results of the microfinance access model. First, the microfinance access model's result was different from the banking access model for common demographic variables. The profession variable was not significant in the logit model; however, weakly significant at a 90\% confidence level in the Probit model, suggesting that people involved in business were more willing to open a microfinance account. Other two common variables (income and education) have highly significant influence on microfinance access (coefficient $=-5.221 \& p=0.001$, 
Table 8 Regression result of FinTech access and financial literacy. Source: Author's Findings

\begin{tabular}{|c|c|c|c|c|}
\hline \multirow[t]{2}{*}{ FinTech account (DV) } & \multicolumn{2}{|c|}{ Logit model } & \multicolumn{2}{|c|}{ Probit model } \\
\hline & A & B & $A$ & B \\
\hline \multirow[t]{2}{*}{ Profession } & & -0.348 & & -0.113 \\
\hline & & $(0.316)$ & & $(0.170)$ \\
\hline \multirow[t]{2}{*}{ Income } & & $0.490^{* * *}$ & & $0.275^{* *}$ \\
\hline & & $(0.188)$ & & $(0.107)$ \\
\hline \multirow[t]{2}{*}{ Education } & & $0.779 * * *$ & & $0.344^{* *}$ \\
\hline & & $(0.272)$ & & $(0.143)$ \\
\hline \multirow[t]{2}{*}{ Send \& withdraw ability } & 5.089 & $5.312^{* * *}$ & 2.752 & $2.782^{* * *}$ \\
\hline & $(0.490)$ & $(0.502)$ & $(0.209)$ & $(0.206)$ \\
\hline \multirow[t]{2}{*}{ Billpay ability } & -0.69 & -0.750 & -0.268 & -0.323 \\
\hline & $(0.802)$ & $(0.859)$ & $(0.409)$ & $(0.431)$ \\
\hline \multirow[t]{2}{*}{ Software use ability } & 1.396 & $1.811^{* * *}$ & 0.839 & $1.045^{* * *}$ \\
\hline & $(0.435)$ & $(0.491)$ & $(0.247)$ & $(0.271)$ \\
\hline \multirow[t]{2}{*}{ Online dealing ability } & 1.546 & $2.378^{* * *}$ & 0.802 & $1.187^{* *}$ \\
\hline & $(0.792)$ & $(0.887)$ & $(0.442)$ & $(0.477)$ \\
\hline \multirow[t]{2}{*}{ FinTech training } & 1.526 & $1.647^{* * *}$ & 0.869 & $0.903^{* * *}$ \\
\hline & $(0.563)$ & $(0.590)$ & $(0.318)$ & $(0.320)$ \\
\hline \multirow[t]{2}{*}{ _cons } & -1.56 & -0.440 & -0.957 & -0.574 \\
\hline & $(0.155)$ & $(0.622)$ & $(0.086)$ & $(0.346)$ \\
\hline
\end{tabular}

This model presents the association between financial literacy and FinTech access. Part A of the logit model shows - 182.95 log-likelihood, $\mathrm{LR} \mathrm{chi}^{2}(5)$ is 679.05 , and model fits at $65 \%$ Pseudo $\mathrm{R}^{2}$ value; where part B shows - 173.75 log-likelihood, LR $\mathrm{chi}^{2}(8)$ is 697.46 , and model fits at $67 \%$ Pseudo $\mathrm{R}^{2}$ value. On the other hand, Part A of the Probit model shows - 181.77 loglikelihood, $\mathrm{LR} \mathrm{Chi}^{2}(5)$ is 681.4, and the model fits at $65 \%$ Pseudo $\mathrm{R}^{2}$ value; where part B shows - 176.63 log-likelihood, LR chi (8) is 695.7 , and model fits at $67 \%$ Pseudo $R^{2}$ value. The value of Prob $>\mathrm{chi}^{2}$ is 0.000 for all models, and the observation of $A$ $\&$ B is $852 .{ }^{* * *},{ }^{* *},{ }^{*}$ refer significance level at $99 \%, 95 \%, 90 \%$, respectively. The value within the first bracket is the standard error value

and coefficient $=1.756 \& p=0.008$, respectively). The findings indicated that lowerincome but comparatively higher-educated people are more likely to open a microfinance account. Though the education variable was highly significant in the logit model at $99 \%$ confidence level, the probit model showed a lower confidence level at only $95 \%$.

For the other variables, similar to the banking access model, knowledge regarding depositing into a bank and withdraw from the bank, and savings and loan interest rates variables were highly and positively significant (coefficient is 22.55 and $p$-value is 0.000 , and the coefficient is 4.58 and $p$-value is 0.002 , respectively). The identical results were reported for knowledge regarding savings and loan and security money variables (Coefficient is $5.911 \& p$-value is 0.000 , and the coefficient is $4.708 \& p$-value is 0.002 , respectively). The findings suggested that more literate respondents towards deposit, withdrawal, savings, and loans had a higher probability of getting microfinance access. The personal investment negatively impacted the participants' access to microfinance, showing the lower capability of seeking microfinance help led to a higher possibility of opening a microfinance account. Security knowledge was positively associated with microfinance access. Finally, knowledge regarding personal investment variable was found to impact microfinance access negatively. People who have better investment knowledge seemed to less use microfinance services.

Equation (4) presents the FinTech access model, which is given as below: 
Table 9 Robustness checking with complementary log-log regression. Source: Authors' experiment

\begin{tabular}{|c|c|c|c|}
\hline \multirow[t]{2}{*}{ Covariates } & \multicolumn{3}{|c|}{ Complementary log-log regression } \\
\hline & Banking & Microfinance & FinTech \\
\hline \multirow[t]{2}{*}{ Profession } & $2.498^{* * *}$ & $-1.346^{* *}$ & -0.068 \\
\hline & $(0.502)$ & $(0.619)$ & $(0.201)$ \\
\hline \multirow[t]{2}{*}{ Income } & $2.415^{* * *}$ & $-3.070^{* * *}$ & $0.266^{* *}$ \\
\hline & $(0.604)$ & $(0.845)$ & $(0.133)$ \\
\hline \multirow[t]{2}{*}{ Education } & $1.246^{* * *}$ & $0.650^{*}$ & -0.169 \\
\hline & $(0.325)$ & $(0.380)$ & $(0.181)$ \\
\hline \multirow[t]{2}{*}{ Deposit \& withdraw ability } & $6.086^{* * *}$ & $10.907^{* * *}$ & \\
\hline & $(0.866)$ & $(2.697)$ & \\
\hline \multirow[t]{2}{*}{ DPS \& loan } & 0.624 & $2.788^{* * *}$ & \\
\hline & $(0.395)$ & $(0.758)$ & \\
\hline \multirow[t]{2}{*}{ DPS \& loan interest rate } & $2.734^{* * *}$ & $2.449^{* * *}$ & \\
\hline & $(0.535)$ & $(0.725)$ & \\
\hline \multirow[t]{2}{*}{ Installment } & 0.217 & $0.617^{*}$ & \\
\hline & $(0.231)$ & $(0.353)$ & \\
\hline \multirow[t]{2}{*}{ Security money } & -0.343 & $2.467^{* * *}$ & \\
\hline & $(0.441)$ & $(0.667)$ & \\
\hline \multirow[t]{2}{*}{ Personal investment } & & $-1.832^{* * *}$ & \\
\hline & & $(0.570)$ & \\
\hline \multirow[t]{2}{*}{ FT send \& withdraw } & & & $2.738^{* * *}$ \\
\hline & & & $(0.188)$ \\
\hline \multirow[t]{2}{*}{ Billpay ability } & & & -0.309 \\
\hline & & & $(0.393)$ \\
\hline \multirow[t]{2}{*}{ Software use ability } & & & $1.073^{* * *}$ \\
\hline & & & $(0.342)$ \\
\hline \multirow[t]{2}{*}{ Online dealing ability } & & & $1.320^{* *}$ \\
\hline & & & $(0.531)$ \\
\hline \multirow[t]{2}{*}{ FinTech training } & & & $0.910^{* *}$ \\
\hline & & & $(0.379)$ \\
\hline \multirow[t]{2}{*}{ cons } & -12.68 & -10.016 & -1.684 \\
\hline & (1.974) & $(5.102)$ & $(0.423)$ \\
\hline
\end{tabular}

This model defines the robustness test of all models with Complementary Log-log regression. The banking model

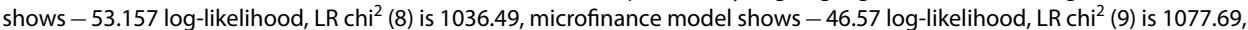
FinTech model shows - $178.60 \log$-likelihood, $\mathrm{LR} \mathrm{chi}{ }^{2}(8)$ is 687.76. The value of Prob $>\mathrm{chi}^{2}$ is 0 for all models, and the observation of A \& B is 852 . ${ }^{* * *}, * * *$ refer significance level at $99 \%, 95 \%, 90 \%$, respectively. The value within the first bracket is the standard error value

$$
\begin{aligned}
& \text { Logit (FinTech Account) }=\beta_{0}+\beta_{1} * \text { Profession }+\beta_{2} * \text { Income }+\beta_{3} * \text { Education } \\
& \quad+\beta_{4} * \text { Send \& Withdraw Ability }+\beta_{5} * \text { Billpay Ability } \\
& +\beta_{6} * \text { Software Using Ability }+\beta_{7} * \text { Online Dealing Ability }+\beta_{8} * \text { FinTech Training }
\end{aligned}
$$

In Eq. (4), the dependent variable is the usage of FinTech (mainly mobile money) account. Both the dependent and independent variables are dummy variables with binary code. They have coded 1 if the respondent had a positive response (Yes) and coded 0 if the respondent provided a negative response (No).

Table 8 presents the regression results of the FinTech access model. This model experienced a comparatively lower value of Pseudo $\mathrm{R}^{2}$ compared to the other two models 
for banking access and microfinance access. However, there were still 70\% of respondents who have access to financial technology. The majority of respondents coming from lower-income and less educated groups did not show their interest in using any FinTech devices or mobile money. Income and education showed a positive relationship with FinTech access at the significant level of $99 \%$ (coefficient $0.490 \& 0.779$, respectively). These two variables had a lower effect on FinTech access compared to banking and microfinance access. Like the other two access methods, money sending and withdrawal ability were highly associated with Fintech access (coefficient is 5.312 and $p$-value is 0.000 ). Besides, software using ability, online dealing ability, and fintech training are positively related to FinTech usage, particularly for mobile money account. The result shows a currently increasing trend when more people have been using software for FinTech activities and online shopping.

\section{Robustness}

Logistic and probit regression models are commonly used for analysing binary response data, but these models' maximum likelihood estimators are not robust to outliers. The robustness of the method is tested using real and simulated data sets. This study used a complementary log-log regression model to check the other two models' acceptability, logit \& probit. Table 9 and the logit models' results indicate that most of the variables' value was similar to the complementary log-log regression model. In some cases, there were slight differences in $p$-value; however, these were insignificant to consider for any decision.

\section{Discussion \& conclusion}

\section{Discussion}

Financial access is the leading factor in promoting rural finance and financial inclusion. Our study aimed to examine the impact of financial knowledge on accessing financial products and services in Bangladesh, using the logit model, probit model, and complementary log-log regression model. For this study, we consider three approaches to getting financial access: banking, microfinance, and FinTech (mobile banking). Some variables showed insignificant results due to participants' poor responses, supporting the assumption that respondents were not familiar with those financial activities; Their lack of knowledge about financial activities was considered the obstacle for preventing financial access development. Overall, the empirical findings demonstrated that financial literacy had a positive effect on access to finance. Financial knowledge was one of the most influential forces to enhance financial inclusion. It is expected to provide a significant contribution toward promoting financial communication for rural and lower-income people. Proper knowledge regarding different financial services influenced strongly in getting financial access and extending other financial services. Rural respondents' knowledge was limited to a small number of banking services and activities. The financial institutions have not paid enough attention to educating people from rural areas about financial access. 
The three models' results indicated that people were not familiar with any financial training, which might positively influence future financial inclusion. Only $14 \%, 6 \%$, and $18 \%$ of people had proper banking, microfinance, and FinTech uses, respectively. Koomson et al. (2019) revealed that financial literacy training significantly impacted account ownership, and financial literacy training beneficiaries were more likely to intensify inclusive finance. Besides, this study recommended that financial literacy training might reduce the financial gap.

First, demographic variables significantly impacted banking, microfinance, and FinTech access. Higher-income level groups were more likely to be the bank account holder and FinTech users. Grohmann et al. (2018) specified that income was usually related to financial literacy. The opposite trends were reported for microfinance, where people at lower-income levels had a higher probability of using microfinance products and services. This can be explained by the popularity of microfinance for poor people. Microfinance, as the banking for poor people, was introduced broadly by Nobel laureate Professor Muhammad Yunus. Similarly, the profession also highly positively affected banking access and showed a negative influence on microfinance. Education played an important role in individuals' banking and microfinance access, although its impact on FinTech access was not clear. Though FinTech users accounted for $70 \%$ of respondents, which was higher than the number of banking and microfinance account holders $(60 \%$ and $45 \%$, respectively), respondents were less familiar with FinTech services. This result was in line with the literature (Morgan and Trinh 2019; Kodongo 2018), which emphasised financial literacy as a determinant to increase financial inclusion.

People seemed to know better about banking services than those of another two access options. More knowledge regarding financial services and activities led to more accounts open in financial institutions. Knowledge regarding bank savings and loans, instalment, and security money seemed to not affect the financial access. For example, individuals' good knowledge of the instalment procedure did not affect their access to microfinance. However, in the literature, increasing financial literacy would increase account ownership (Grohmann et al. 2018).

As stated earlier in the discussion section, respondents were not familiar with FinTech products and services; thus, there is a big platform to enhance financial inclusion through FinTech access. As basic training on FinTech services was not deployed widely to the whole population, most people only used Fintech services for sending and withdrawing money. Proper knowledge regarding other FinTech activities may help them to utilise more effectively those financial technology applied services.

\section{Theoretical and practical implication}

Rural consumers' knowledge about financial services is a new aspect of inclusive finance research. This study will significantly contribute to the study on financial literacy concept. It mainly highlights the importance of knowledge regarding specific products and services to promote financial inclusion. The idea of financial literacy is still underway to be included as a core issue of finance, both in the theoretical and practical perspectives. Our research emphasises the importance of financial literacy to include excluded people from formal financial systems. These excluded people came from the unprivileged and vulnerable groups in rural areas. More financial training and education will inspire rural 
consumers to involve in financial services. The rural consumers will be equipped with the knowledge to select suitable financial products and services. The study's empirical findings also provide valuable recommendations for the policymaker to improve financial inclusion in the developing country context. A comprehensive and long-term education program should be introduced broadly to the rural population to make a big stride in financial inclusion, a key driver of poverty reduction and prosperity boosting.

\section{Conclusion}

Financial literacy is considered as one of the vital factors of financial inclusion. Rural people who have better knowledge of financial services $\mathrm{s} /$ she has more possibility to be included into formal financial systems. Based on these concepts, this study was conducted. In order to investigate the likelihood of getting financial access (banking, microfinance, and fintech), mainly two experimental models were experimented in this study; the logit model, and probit model. Also, the complementary log-log regression model was used to test robustness of the primary models. Usually, the probit model and a complementary log-log regression model are the two common models used as the alternative model to logistic regression. Whatever, after investigating the findings of this research, this study concludes that knowledge regarding financial services is one of the most influential forces to promote inclusive finance. It also has a significant contribution to developing financial communication capabilities for rural and lower-income countryside people. Proper understanding of different financial services has a significant impact on access to financial opportunities, especially the expansion of the use of other financial services. Rural people only know a limited number of banking services and activities; this is why, they continue to be limited to these services. In most cases, they believe that the only activities of banks are also limited to deposits and withdrawals from banks. This is the reason for why they do not go for other financial services. In addition, financial institutions have not yet arranged any obvious training programs to stimulate access to financial opportunities. All the common covariates can have a significant impact on financial access, but it depends on each access pattern. In any case, there are also several challenges that exist in getting financial access. These works are considered as the major obstacle to the promotion of inclusive finance. More specifically, the interviewee only knew about the general services of banking, microfinance, and financial technology access. Even, financial institutions have not carried out such activities to literate rural people about financial access. For example, the banking training and microfinance training were insignificant and dropped from the main model due to very poor response. This is also considerd here as a significant limitation. Usually, institutions use the advertising policies to inform rural people about services; however, this study considered these advertising policies are not enough to inform the rural people about financial products or services.

\section{Future research scope}

Future studies could be undertaken for different countries and regions, such as other underdeveloped and developing countries, where financial inclusion is still an emerging issue. Studies examine the measure of financial knowledge and compare this factor between low-income rural groups and high-income educated people are in need. The 
proposal of an index for financial literacy, especially in underdeveloped and developing countries, could be conducted. As financial technology has become the most emerging financial communication approach, avenues for possible future research focusing on financial innovation training and developing FinTech access to all population groups are also open.

\section{Appendix}

Source: Authors' explanation.

\begin{tabular}{|c|c|c|c|c|}
\hline & Variance & Coef & Std. Err & $\begin{array}{l}\text { [95\% Conf. } \\
\text { Interval] }\end{array}$ \\
\hline \multicolumn{5}{|l|}{ Banking } \\
\hline Var (e.Profession) & 0.9839 & 0.0086 & 0.9673 & 1.0008 \\
\hline Var (e.Income) & 0.7316 & 0.0260 & 0.6824 & 0.7843 \\
\hline Var (e.Education) & 0.7845 & 0.0250 & 0.7371 & 0.8350 \\
\hline $\operatorname{Var}$ (e.Deposit \& Withdraw Ability) & 0.1682 & 0.0105 & 0.1488 & 0.1901 \\
\hline $\operatorname{Var}($ e.DPS \& Loan) & 0.4689 & 0.0234 & 0.4252 & 0.5171 \\
\hline Var (e.DPS \& Loan Interest rate) & 0.5188 & 0.0247 & 0.4726 & 0.5694 \\
\hline $\operatorname{Var}(\mathrm{e}$. Instalment) & 0.5651 & 0.0255 & 0.5172 & 0.6174 \\
\hline Var (e.Security Money) & 0.6322 & 0.0263 & 0.5827 & 0.6858 \\
\hline \multicolumn{5}{|l|}{ Microfinance } \\
\hline Var (e.Profession) & 0.7158 & 0.0139 & 0.6890 & 0.7436 \\
\hline Var (e.Income) & 0.9978 & 0.0032 & 0.9916 & 1.0041 \\
\hline $\operatorname{Var}($ e.Education) & 0.9810 & 0.0093 & 0.9630 & 0.9993 \\
\hline $\operatorname{Var}$ (e.Deposit \& Withdraw Ability) & 0.1870 & 0.0116 & 0.1657 & 0.2111 \\
\hline $\operatorname{Var}(e . D P S \&$ Loan) & 0.2364 & 0.0183 & 0.3565 & 0.4233 \\
\hline Var (e.DPS \& Loan Interest rate) & 0.6125 & 0.0261 & 0.5634 & 0.6659 \\
\hline $\operatorname{Var}(\mathrm{e}$. Instalment) & 0.4174 & 0.0218 & 0.3767 & 0.4624 \\
\hline Var (e.Security Money) & 0.4674 & 0.0234 & 0.4238 & 0.5156 \\
\hline Var (e.Personal Investment) & 0.5992 & 0.0260 & 0.5503 & 0.6523 \\
\hline \multicolumn{5}{|l|}{ FinTech } \\
\hline Var (e.Profession) & 0.6972 & 0.0145 & 0.6694 & 0.7261 \\
\hline $\operatorname{Var}($ e.Income) & 0.9257 & 0.0173 & 0.8924 & 0.9602 \\
\hline Var (e.Education) & 0.8522 & 0.0225 & 0.8093 & 0.8973 \\
\hline Var (e.FT Send \& Withdraw) & 0.3443 & 0.0191 & 0.3088 & 0.3839 \\
\hline Var (e.Billpay ability) & 0.7224 & 0.0261 & 0.6731 & 0.7754 \\
\hline Var (e.Software Use Ability) & 0.8509 & 0.0225 & 0.8079 & 0.8962 \\
\hline Var (e.Online Dealing Ability) & 0.9301 & 0.0169 & 0.8976 & 0.9637 \\
\hline $\operatorname{Var}($ e.FinTech Training) & 0.8270 & 0.0236 & 0.7821 & 0.8745 \\
\hline
\end{tabular}

Acknowledgements

We will be grateful to the anonymous reviewers who commented on our manuscript.

Authors' contributions

The concept, design, methods, result analysis, paper writing (Morshadul Hasan), Introduction, discussion, implications, and conclusion (Thi Le), editing, revising, proofreading, language editing (Ariful Hoque).

Authors' informations

Morshadul Hasan is currently enrolled as a PhD student (Finance) at Murdoch University, WA 6150, Australia. He has completed his Masters in Finance from Nanjing Audit University, China. His research interests include inclusive finance, financial literacy, big data, machine learning, fintech, and so on. He has nearly 5 years of academic experiences. He has several SSCI \& SCOPUS Q1 and Q2 level publications. Currently, some of his research projects are under review on SSCI Q1 and ABDC A level journals such as Annals of Operation Research, Finance Research Letter, Journal of Knowledge 
Economy, European Finance Journal, Journal of Big Data, and so other Q2 level journals. Dr. Thi Le, Ph.D. is a Research Associate at Murdoch University, Australia. She served both industries and academia with ten years of teaching experiences in Finance and Accounting and working experiences in several industry projects. Her research interests include derivatives, financial forecasting, fintech, supply chain, and accounting framework. She has published many research papers in prominent international journals, conferences and received a number of industry grants. Dr. Ariful Hoque, Ph.D. is a senior lecturer at Murdoch University, Australia. He joined the Murdoch Business School in February 2012 as Senior Lecturer in Finance. He earned his Doctor of Philosophy (Ph.D.) in Finance from Curtin University (Australia). He held different positions in the industry for thirteen (13) years before commencing my academic profession. He worked as a business analyst, programmer and software developer for several well-reputed organisations, including St George Bank (Australia) and Air New Zealand (New Zealand). He has had seventeen (17) years of experience teaching in all areas of Finance, including research methodology and data analytics to undergraduate and postgraduate students at Curtin University, University of Dubai (AACSB accredited), University of Southern Queensland, University of South Australia, and Murdoch University. His research interest areas (alphabetically) include, but are not limited to, Data Analytics, Derivatives, Financial Engineering, Fintech and Market Micro Structure. He has published his research works in various journals including Energy Economics, International Review of Economics and Finance, Pacific-Basin Finance Journal, Global Finance Journal, International Journal of Managerial Finance, Energy Policy and Multinational Finance Journal. He has also received several grants and awards for excellence in research.

\section{Funding}

There is no specified project funding.

Availability of data and materials

Our data will be available on request.

\section{Declarations}

Competing interests

There is no competing interest between the authors.

Received: 5 October 2020 Accepted: 24 May 2021

Published online: 03 June 2021

\section{References}

Agyei SK (2018) Culture, financial literacy, and SME performance in Ghana. Cogent Econ Finance. https://doi.org/10.1080/ 23322039.2018 .1463813

Atkinson A (2015) Guide to creating financial literacy scores and financial inclusion indicators using data from the OECD/ INFE 2015 financial literacy survey (issue September). http://www.oecd-ilibrary.org/finance-and-investment/measu ring-financial-literacy_5k9csfs90fr4-en

Atkinson A (2017) G20/Oecd Infe Report on Audit Financial Literacy in G20 countries. www.oecd.org/finance/financialeducation

Atkinson A, Messy F-A (2012) Measuring financial literacy: results of the OECD. In: OECD working papers on finance, insurance and private pensions no. 15 (issue 15). https://doi.org/10.1111/j.1745-6606.2010.01170.x

Belayeth Hussain AHM, Endut N, Das S, Chowdhury MTA, Haque N, Sultana S, Ahmed KJ (2019) Does financial inclusion increase financial resilience? Evidence from Bangladesh. Dev Pract. https://doi.org/10.1080/09614524.2019.1607256

Berry J, Karlan D, Pradhan M (2018) The impact of financial education for youth in Ghana. World Dev 102:71-89. https:// doi.org/10.1016/j.worlddev.2017.09.011

Bhaskar, P. V. (2013). Financial inclusion in India—an assessment 1. In: MFIN and Access-Assist Summit organised in New Delhi

Bianchi M (2018) Financial literacy and portfolio dynamics. J Finance 73(2):831-859. https://doi.org/10.1111/jofi.12605

Bijli HK (2012) Financial literacy: an essential tool for empowerment of women through micro-finance. Stud Home Community Sci 6(2):77-85. https://doi.org/10.1080/09737189.2012.11885370

Bongini P, lannello P, Rinaldi EE, Zenga M, Antonietti A (2018) The challenge of assessing financial literacy: alternative data analysis methods within the Italian context. Empir Res Vocat Educ Train. https://doi.org/10.1186/s40461-018-0073-8

Bongomin GOC, Ntayi JM, Munene JC, Nabeta IN (2016a) Financial inclusion in rural Uganda: testing interaction effect of financial literacy and networks. J Afr Bus 17(1):106-128. https://doi.org/10.1080/15228916.2016.1117382

Bongomin GOC, Ntayi JM, Munene JC, Nkote Nabeta I (2016b) Social capital: mediator of financial literacy and financial inclusion in rural Uganda. Rev Int Bus Strat 26(2):291-312. https://doi.org/10.1108/RIBS-06-2014-0072

Brown A, Slagter van Tryon PJ (2010) Twenty-first century literacy: a matter of scale from micro to mega. Clear House: J Educ Strat Issues Ideas 83(6):235-238. https://doi.org/10.1080/00098655.2010.484438

Casanova L, Cornelius PK, Dutta S (2018) Banks, credit constraints, and the financial technology's evolving role. In: Financing entrepreneurship and innovation in emerging markets, pp 161-184. https://doi.org/10.1016/B978-0-12-8040256.00007-1

Chao X, Kou G, Peng Y, Viedma EH (2021) Large-scale group decision-making with non-cooperative behaviors and heterogeneous preferences: An application in financial inclusion. Eur J Oper Res 288(1):271-293. https://doi.org/10. 1016/j.ejor.2020.05.047

Claessens S, Glaessner T, Klingebiel D (2002) Electronic finance: reshaping the financial landscape around the world. J Financ Serv Res 22(1-2):29-61. https://doi.org/10.1023/A:1016023528211 
Cull R, Demirgüç-Kunt A, Morduch J (2009) Microfinance meets the market. J Econ Perspect 23(1):167-192. https://doi. org/10.1257/jep.23.1.167

Cull R, Morduch J (2018) Microfinance and economic development. In: Handbook of finance and development, pp 550-572. https://doi.org/10.4337/9781785360510.00030

Demirguc-Kunt A, Klapper L, Singer D, Ansar S, Hess J (2017) The Global Findex Database 2017: measuring financial inclusion and the Fintech Revolution. https://doi.org/10.1596/978-1-4648-1259-0

Feng X, Lu B, Song X, Ma S (2019) Financial literacy and household finances: a Bayesian two-part latent variable modeling approach. J Empir Financ 51(February):119-137. https://doi.org/10.1016/j.jempfin.2019.02.002

Fernandes D, Lynch JG, Netemeyer RG (2014) The effect of financial literacy on downstream financial behaviors. Manag Sci. https://doi.org/10.1287/mnsc.2013.1849

Frisancho V (2019) The impact of financial education for youth. Econ Educ Rev. https://doi.org/10.1016/..econedurev. 2019.101918

Gai K, Qiu M, Sun X (2018) A survey on FinTech. J Netw Comput Appl 103:262-273. https://doi.org/10.1016/j.jnca.2017.10. 011

Gimpel H, Rau D, Röglinger M (2017) Understanding FinTech start-ups-a taxonomy of consumer-oriented service offerings. Electron Mark. https://doi.org/10.1007/s12525-017-0275-0

Grohmann A, Klühs T, Menkhoff L (2018) Does financial literacy improve financial inclusion? Cross country evidence. World Dev 111:84-96. https://doi.org/10.1016/j.worlddev.2018.06.020

Hasan MM, Popp J, Oláh J (2020a) Current landscape and influence of big data on finance. J Big Data 7(1):21. https://doi. org/10.1186/s40537-020-00291-z

Hasan MM, Yajuan L, Khan S (2020b) Promoting China's inclusive finance through digital financial services. Global Bus Rev. https://doi.org/10.1177/097215091989534

Hasan MM, Yajuan L, Mahmud A (2020c) Regional development of China's inclusive finance through financial technology. SAGE Open 10(1):215824401990125. https://doi.org/10.1177/2158244019901252

Hassan Al-Tamimi HA, Anood Bin Kalli A (2009) Financial literacy and investment decisions of UAE investors. J Risk Finance 10(5):500-516. https://doi.org/10.1108/15265940911001402

Helms B (2006) Access for all consultative group to assist the poor.https://doi.org/10.1596/978-0-8213-6360-7

Hill J, Hill J (2018) Fintech and Government Regulation. FinTech and the Remaking of Financial Institutions, pp 285-314. https://doi.org/10.1016/B978-0-12-813497-9.00015-9

Hogarth JM (2006) Financial education and economic development. In: International conference hosted by the Russian G8 Presidency in cooperation with the OECD, pp 72-94

Hussain J, Salia S, Karim A (2018) Is knowledge that powerful? Financial literacy and access to finance: an analysis of enterprises in the UK. J Small Bus Enterp Dev 25(6):985-1003. https://doi.org/10.1108/JSBED-01-2018-0021

Huston SJ (2010) Measuring financial literacy. J Consum Aff 44(2):296-316. https://doi.org/10.1111/j.1745-6606.2010. 01170.x

Johnston JD (2005) Importance of financial literacy in the global economy. The Financial Education Summit, Kuala Lumpur, December, 5. https://www.oecd.org/general/35883324.pdf

Kadoya Y, Khan MSR, Hamada T, Dominguez A (2018) Financial literacy and anxiety about life in old age: evidence from the USA. Rev Econ Household 16(3):859-878. https://doi.org/10.1007/s11150-017-9401-1

Kezar A, Yang H (2010) The importance of financial literacy. About Campus 14(6):15-21. https://doi.org/10.1002/abc. 20004

Kiliyanni AL, Sivaraman S (2018) A predictive model for financial literacy among the educated youth in Kerala, India. J Soc Serv Res 44(4):537-547. https://doi.org/10.1080/01488376.2018.1477699

Kodongo O (2018) Financial regulations, financial literacy, and financial inclusion: insights from Kenya. Emerg Mark Financ Trade 54(12):2851-2873. https://doi.org/10.1080/1540496X.2017.1418318

Koomson I, Villano RA, Hadley D (2019) Intensifying financial inclusion through the provision of financial literacy training: a gendered perspective. Appl Econ 52(4):1-13. https://doi.org/10.1080/00036846.2019.1645943

Kou G, Xu Y, Peng Y, Shen F, Chen Y, Chang K, Kou S (2021) Bankruptcy prediction for SMEs using transactional data and two-stage multiobjective feature selection. Decis Support Syst 140:113429. https://doi.org/10.1016/j.dss.2020 113429

Le TH, Chuc AT, Taghizadeh-Hesary F (2019) Financial inclusion and its impact on financial efficiency and sustainability: empirical evidence from Asia. Borsa Istanbul Rev 19(4):310-322. https://doi.org/10.1016/j.bir.2019.07.002

LightCastle Partners (2019) The state of digital microfinance in Bangladesh

Lusardi A (2012) Numeracy, financial literacy, and financial decision-making. Numeracy 5(1):1-12. https://doi.org/10. 5038/1936-4660.5.1.2

Lusardi A, Michaud PC, Mitchell OS (2019) Assessing the impact of financial education programs: a quantitative model. Econ Educ Rev. https://doi.org/10.1016/.econedurev.2019.05.006

Lusardi A, Mitchell OS (2011) Financial literacy: implication for retirement wellbeing. In: NBER working paper series (No. 17078; NBER WORKING PAPER SERIES). http://www.nber.org/papers/w17078

Lusardi A, Mitchell OS (2014) The economic importance of financial literacy: theory and evidence. J Econ Lit 32(1):7-11. https://doi.org/10.1257/jel.52.1.5

Lyons AC, Kass-Hanna J (2019) Financial inclusion, financial literacy and economically vulnerable populations in the Middle East and North Africa. Emerg Mark Finance Trade. https://doi.org/10.1080/1540496X.2019.1598370

Maturana G, Nickerson J (2019) Teachers teaching teachers: the role of workplace peer effects in financial decisions. Rev Finance Stud 32(10):3920-3957. https://doi.org/10.1093/rfs/hhy136

Mogilevskii R, Asadov S (2018) Financial inclusion, regulation, financial literacy, and financial education in Tajikistan. SSRN Electron J. https://doi.org/10.2139/ssrn.3187118

Morduch J (1999) The microfinance promise. J Econ Lit 37(4):1569-1614. https://doi.org/10.1257/jel.37.4.1569

Morgan P, Trinh L (2019) Determinants and impacts of financial literacy in Cambodia and Viet Nam. J Risk Financ Manag 12(1):19. https://doi.org/10.3390/jrfm12010019 
Nawaz F (2015) Microfinance, financial literacy, and household power configuration in rural Bangladesh: an empirical study on some credit borrowers. VOLUNTAS: Int JVolunt Nonprofit Organ 26(4):1100-1121. https://doi.org/10.1007/ s11266-015-9585-z

OECD (2011) Measuring financial literacy: questionnaire and guidance notes for conducting an internationally comparable survey of financial literacy. 8th meeting of the international network on financial education, pp 1-31

Opletalová A (2015) Financial education and financial literacy in the Czech education system. Procedia Soc Behav Sci 171:1176-1184. https://doi.org/10.1016/j.sbspro.2015.01.229

Ouma SA, Odongo TM, Were M (2017) Mobile financial services and financial inclusion: is it a boon for savings mobilization? Rev Dev Finance 7(1):29-35. https://doi.org/10.1016/j.rdf.2017.01.001

Paiella M (2016) Financial literacy and subjective expectations questions: a validation exercise. Res Econ 70(2):360-374. https://doi.org/10.1016/j.rie.2015.11.004

Patwardhan A, Singleton K, Schmitz K (2018) Financial inclusion in the digital age. March. https://www.ifc.org/wps/wcm/ connect/f5784538-6812-4e06-b4db-699e86a0b2f2/Financial+Inclusion+in+the+Digital+Age.PDF?MOD=AJPER ES

Pompei F, Selezneva E (2019) Unemployment and education mismatch in the EU before and after the financial crisis. J Policy Model. https://doi.org/10.1016/j.jpolmod.2019.09.009

Postmus JL, Plummer SB, McMahon S, Zurlo KA (2013) Financial literacy: building economic empowerment with survivors of violence. J Fam Econ Issues 34(3):275-284. https://doi.org/10.1007/s10834-012-9330-3

Rashidin MS, Javed S, Chen L, Jian W (2020a) Assessing the competitiveness of Chinese multinational enterprises development: evidence from electronics sector. SAGE Open. https://doi.org/10.1177/2158244019898214

Rashidin MS, Javed S, Liu B, Jian W (2020b) Ramifications of households' nonfarm income on agricultural productivity: evidence from a rural area of Pakistan. SAGE Open. https://doi.org/10.1177/2158244020902091

Salampasis D, Mention A-L (2018) FinTech: harnessing innovation for financial inclusion. In: Handbook of blockchain, digital finance, and inclusion, 1st edn., vol 2. Elsevier Inc. https://doi.org/10.1016/B978-0-12-812282-2.00018-8

Segre M (2018) Financial literacy and financial inclusion in Vietnam: a way back and forth Study Report (Issue February). http://mefin.org/files/GIZRFPI_Vietnam_FinancialLiteracy_financialinclusion.pdf

Shen Y, Hueng CJ, Hu W (2019) Using digital technology to improve financial inclusion in China. Appl Econ Lett 00(00):15. https://doi.org/10.1080/13504851.2019.1606401

Sinha S, Pandey KR, Madan N (2018) Fintech and the demand side challenge in financial inclusion. Enterp Dev Microfinance 29(1):94-98. https://doi.org/10.3362/1755-1986.17-00016

Stein P (2010) Towards universal access: financial inclusion: addressing the global challenge of financial inclusion. In: Korea-World Bank high level conference on post-crisis growth and development, pp 1-35

Sun H, Yuen DCY, Zhang J, Zhang X (2020) Is knowledge powerful? Evidence from financial education and earnings quality. Res Int Bus Finance 52:101179. https://doi.org/10.1016/j.ribaf.2019.101179

Sun T (2017) Balancing innovation and risks in digital financial inclusion-experiences of ant financial services group. In: Handbook of blockchain, digital finance, and inclusion, 1st edn., vol 2. Elsevier Inc. https://doi.org/10.1016/B978-012-812282-2.00002-4

Urban C, Schmeiser M, Michael Collins J, Brown A (2018) The effects of high school personal financial education policies on financial behavior. Econ Educ Rev. https://doi.org/10.1016/j.econedurev.2018.03.006

van Rooij M, Lusardi A, Alessie R (2011) Financial literacy and stock market participation. J Financ Econ 101(2):449-472. https://doi.org/10.1016/j.jineco.2011.03.006

Von Gaudecker HM (2015) How does household portfolio diversification vary with financial literacy and financial advice? J Finance 70(2):489-507. https://doi.org/10.1111/jofi.12231

Wall LD (2017) FinTech and Financial Inclusion in China (Issue 20)

Wang H, Kou G, Peng Y (2020) Multi-class misclassification cost matrix for credit ratings in peer-to-peer lending. J Oper Res Soc. https://doi.org/10.1080/01605682.2019.1705193

Williams OJ, Satchell SE (2011) Social welfare issues of financial literacy and their implications for regulation. J Regul Econ 40(1):1-40. https://doi.org/10.1007/s11149-011-9151-6

Worthington AC (2016) Financial literacy and financial literacy programmes in Australia. Financ Lit Limits Financ DecisMak 18(June):281-301. https://doi.org/10.1007/978-3-319-30886-9_14

Zavolokina L, Dolata M, Schwabe G (2016) The FinTech phenomenon: antecedents of financial innovation perceived by the popular press. Financ Innov 2(1):16. https://doi.org/10.1186/s40854-016-0036-7

Zulkhibri M (2016) Financial inclusion, financial inclusion policy and Islamic finance. Macroecon Finance Emerg Mark Econ 9(3):303-320. https://doi.org/10.1080/17520843.2016.1173716

\section{Publisher's Note}

Springer Nature remains neutral with regard to jurisdictional claims in published maps and institutional affiliations. 